\title{
Increased serum leptin level in overweight patients with colon carcinoma: A cross-sectional and prospective study
}

\author{
DI WANG $^{1 *}$, LICHEN GAO ${ }^{2 *}$, KUIYU GONG $^{1}$, QIN CHAI $^{1}$ and GUIHUA WANG ${ }^{1}$ \\ Departments of ${ }^{1}$ Oncology and ${ }^{2}$ Pharmacy, Changsha Central Hospital, Changsha, Hunan 410004, P.R. China
}

Received May 19, 2016; Accepted September 23, 2016

DOI: $10.3892 /$ mco.2016.1087

\begin{abstract}
Leptin is associated with carcinogenesis and progression of various cancers. However, the changes of the serum leptin level in Chinese overweight patients with colon carcinoma and its association with response to treatment in these patients have rarely been investigated. A total of 63 Chinese overweight patients with colon cancer and 40 body mass index-matched control subjects were recruited in the present study. The serum leptin levels of colon cancer patients prior to and 21 days after colectomy, as well as those of healthy controls, were measured and compared. In addition, the focal expression of phosphorylated Akt, mammalian target of rapamycin and 70S6 Kinase (p-Akt, p-mTOR and P-70S6 Kinase) and leptin were determined in the resected specimens and the correlation between serum leptin levels and the focally expressed markers were investigated. The serum leptin levels of colon cancer patients were significantly higher compared with those of the controls $(22.67 \pm 12.56$ vs. $12.68 \pm 7.8 \mathrm{ng} / \mathrm{ml}$, respectively; $\mathrm{P}<0.05)$. Moreover, the leptin levels decreased after the operation when compared to the preoperative levels $(18.67 \pm 8.54$ vs. $22.67 \pm 12.56 \mathrm{ng} / \mathrm{ml}$, respectively; $\mathrm{P}<0.05)$. In addition, there was a significant correlation between the serum leptin levels and the focal expression of p-Akt, p-mTOR, $\mathrm{P}-70 \mathrm{~S} 6$ Kinase and leptin $(\mathrm{P}<0.05)$. In conclusion, the leptin levels were elevated in Chinese overweight patients with colon cance these levels decreased following colectomy, indicating that leptin may be associated with colon carcinogenesis. Thus, serum leptin level may be used for early diagnosis and for monitoring the response to treatment of colon carcinoma in overweight Chinese patients.
\end{abstract}

Correspondence to: Dr Di Wang or Dr Guihua Wang, Department of Oncology, Changsha Central Hospital, 161 Shaoshan South Road, Yuhua, Changsha, Hunan 410004, P.R. China

E-mail: di_wang800122@163.com

E-mail: wangguihua5708@163.com

*Contributed equally

Key words: serum leptin, overweight, colon carcinoma, body mass index, Chinese

\section{Introduction}

Leptin, mainly synthesized by adipocytes, is a pleiotropic regulator involving food intake, inflammatory and immune response, cellular apoptosis, angiogenesis and proliferation of different cell types (1-3). However, the effects of leptin on colon cancer remain a matter of debate (4-8). Moreover, the majority of previous studies only included non-overweight patients and focused on Western individuals. The serum leptin levels in overweight Chinese patients with colon carcinoma and the changes in serum leptin levels following treatment have rarely been documented. Thus, the present study was conducted to compare the serum leptin levels between overweight colon cancer Chinese patients and colonoscopy-negative controls, as well as in preoperative and postoperative cancer patients.

\section{Materials and methods}

Patient characteristics and inclusion criteria. Electronic colonoscopy was conducted in all the participants. Patients with suspected cancer were confirmed histologically and cancer-free subjects were identified as controls. The clinical records of all the participants were reviewed. The inclusion criteria were Chinese individuals aged $>18$ years with a body mass index (BMI) of $\geq 25 \mathrm{~kg} / \mathrm{m}^{2}$, whereas the exclusion criteria were dyslipidemia, diabetes mellitus and hypertension. Finally, 63 patients with histologically confirmed colon cancer and 40 control volunteers free of colon cancer were included in the present study.

The weight and height of all the participants were determined and the BMI of each participant was calculated using the quotation: $\mathrm{BMI}=$ weight $(\mathrm{kg}) /$ height $(\mathrm{m})^{2}$. Blood samples $(3 \mathrm{ml})$ were collected from the control subjects and from the patients 3-7 days preoperatively and on the 21th postoperative day. The sera of the blood samples were obtained after centrifugation at $1,000 \mathrm{x} g$ for 20 mins. Thereafter, the samples were stored at $-80^{\circ} \mathrm{C}$ until further analysis. The serum leptin levels were measured using a human leptin ELISA kit (TiterZyme ${ }^{\circledR}$ Enzyme Immunometric Assay Kit; Assay Designs Inc., Ann Arbor, MI, USA).

This study was approved by the Hunan Subject Ethics Subcommittee of the hospital. Informed and written consents were obtained from each subject prior to the commencement of the examinations of the study. 

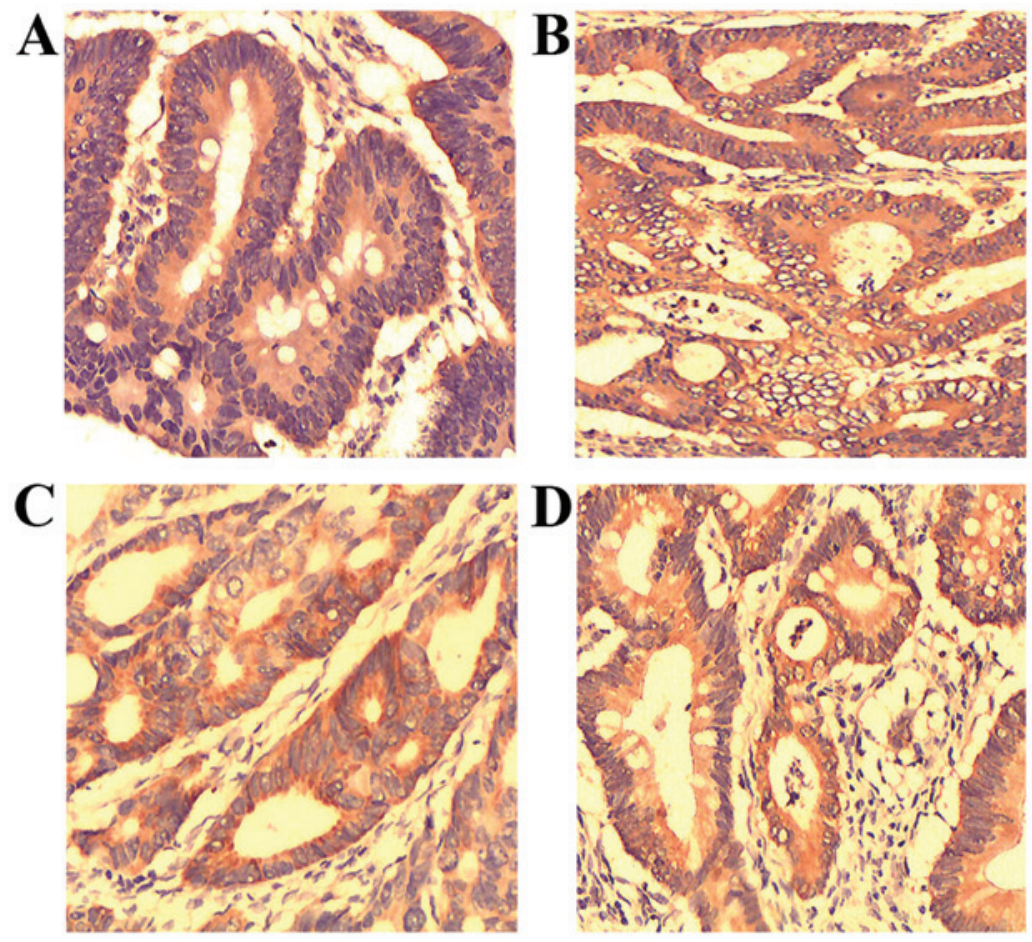

Figure 1. Immunohistochemical staining of a representative colon cancer tissue sample showing protein expression of (A) leptin, (B) p-Akt (C) p-mTOR and (D) P-70S6K (magnification, x20). mTOR, mammalian target of rapamycin.

Immunohistochemistry. The resected specimens were fixed in $10 \%$ formalin, cut into $4-\mu \mathrm{m}$ sections and mounted onto adhesive-coated slides. The slides were deparaffinized in xylene twice for $10 \mathrm{~min}$ and rehydrated through descending concentrations of ethanol. Antigen retrieval was performed in $0.01 \mathrm{M}$ citrate buffer ( $\mathrm{pH}$ 6.0) for $2 \mathrm{~min}$ and $30 \mathrm{sec}$ at $100^{\circ} \mathrm{C}$ using a microwave oven. Endogenous peroxidase activity was blocked with $0.3 \%$ hydrogen peroxidase for $10 \mathrm{~min}$. After washing with Tris-buffered saline, the sections were incubated with blocking serum for $1 \mathrm{~h}$. The sections were then incubated with the following primary antibodies: H-146 rabbit polyclonal antibody for leptin (dilution, 1:200; cat. no. SC-9014, Santa Cruz Biotechnology, Dallas, TX, USA), D9E rabbit polyclonal antibody for phosphorylated (p)-Akt (Ser 473) (dilution, 1:100; cat. no. SC-135651, Santa Cruz Biotechnology), rabbit polyclonal antibody for P-70S6 Kinase (Thr 389) (dilution, 1:100; cat. no. LS-C416604-100, LifeSpan BioSciences, Seattle, WA, USA) and rabbit polyclonal antibody () for p-mammalian target of rapamycin (mTOR) (Ser 2448) (dilution, 1:250; cat. no. SC-101738, Santa Cruz Biotechnology). The sections were then washed and incubated with biotinylated secondary antibody (cat. no. AP21490BT-N, Acris Antibodies GmbH, San Diego, CA, USA) for 30 mins. The immunohistochemical (IHC) staining was evaluated and photographed using an Olympus CX42 microscope (Olympus, Tokyo, Japan). Two independent investigators scored the expression of leptin, p-Akt, p-mTOR and P-70S6K. A scale of 0 (negative), + (weak inmmunoreactivity), ++ (moderate immunoreactivity) and +++ (robust immunoreactivity) was applied according to the intensity of immunolabelling and number of positive cells. Tissues scored as $\geq 1+$ (weak, moderate or robust immunoreactivity) were considered to be positive, whilst those those scoring 0 were considered to be negative. In the IHC analysis, there was no discrepancy between the two observers regarding the patterns of biomarker expression and the scores assigned to analyzed sections.

Statistical analysis. Statistical analyses were performed using SPSS 12.0 software (SPSS Inc., Chicago, IL, USA). Continuous data were expressed as mean \pm standard deviation. The serum leptin levels between groups were compared using the Mann-Whitney U test. The bivariate Pearson correlation was applied to determine the correlation between serum leptin levels and other markers and parameters. P-values $<0.05$ were considered to indicate statistically significant differences.

\section{Results}

Patient characteristics. A total of 63 patients with colon cancer and 40 cancer-free controls were analyzed. All the patients underwent total colectomy, and none of the patients had received chemotherapy or radiotherapy preoperatively. The 63 patients included 29 men and 34 women with an age ranging from 27 to 78 years (median, 61 year mean, 58.4 years). Based on histological grading (9), 13 of the patients had grade 1, 22 had grade 2, and 28 had grade 3 tumors, whilst based on the TNM staging system (http://www.cancer.org/cancer/colonandrectumcancer/detailedguide/colorectal-cancer-staged), 2 had stage I, 14 had stage II, 46 had stage III, and 1 had stage IV disease.

The mean BMI was $27.32 \pm 2.3 \mathrm{~kg} / \mathrm{m}^{2}$ in the control group, and $27.24 \pm 2.0$ and $27.31 \pm 2.1 \mathrm{~kg} / \mathrm{m}^{2}$ before and after colectomy, respectively, in the patient group (Table I). No significant difference in BMI was observed between the patients and the controls, and between patients before and after colectomy.

Colon cancer patients had significantly higher serum leptin levels compared with those in the cancer-free controls 
Table I. Serum leptin levels and BMI in colon cancer patients and cancer-free controls.

\begin{tabular}{llc}
\hline Participants & $\begin{array}{l}\text { Serum leptin } \\
\text { level }(\mathrm{ng} / \mathrm{ml})\end{array}$ & $\begin{array}{c}\text { BMI } \\
\left(\mathrm{kg} / \mathrm{m}^{2}\right)\end{array}$ \\
\hline Preoperative patients $(\mathrm{n}=63)$ & $\mathbf{2 2 . 6 7 \pm \mathbf { 1 2 . 5 6 }}$ & $27.24 \pm 2.0$ \\
Postoperative patients $(\mathrm{n}=63)$ & $\mathbf{1 8 . 6 7} \pm \mathbf{8 . 5 4}$ & $27.31 \pm 2.1$ \\
Cancer-free controls $(\mathrm{n}=40)$ & $12.68 \pm 7.80$ & $27.32 \pm 2.3$ \\
\hline
\end{tabular}

P-values were determined by the Mann-Whitney $\mathrm{U}$ test; $\mathrm{P}<0.05$ is indicated in bold print. BMI, body mass index.

$(22.67 \pm 12.56$ vs. $12.68 \pm 7.8 \mathrm{ng} / \mathrm{ml}$, respectively, $\mathrm{P}<0.05$; Table I). In the colon cancer patients, the serum leptin levels were measured prior to and 21 days after colectomy. The serum leptin level significantly decreased after the operation $(18.67 \pm 8.54$ vs. $22.67 \pm 12.56 \mathrm{ng} / \mathrm{ml}$, respectively, $\mathrm{P}<0.05$; Table I).

Associations between preoperative serum leptin level and clinicopathological factors in colon cancer. In the colon cancer group, there was a significant correlation of the leptin, p-Akt, p-mTOR and P-70S6K status with the serum leptin levels $(\mathrm{P}<0.05$; Fig. 1 and Table II). However, there was no significant association of the serum leptin level with age, gender, or lymph node involvement $(\mathrm{P}>0.05$, Table II).

\section{Discussion}

Colorectal cancer is a major cause of cancer-related mortality and morbidity in Western countries and an increasing health concern in China (10). Epidemiological studies have demonstrated that obesity is associated with an increasing risk of colorectal cancer development and death from colon cancer (11). Leptin may represent a biological link between colon cancer and obesity (6).

The primary aim of the present study was to evaluate serum leptin levels in colon carcinoma patients and compare them to those of cancer-free individuals. A significant increase in serum leptin was observed in colon carcinoma patients. Consistent with our findings, Stattin et al found that higher serum levels of leptin increased the risk of colon cancer (6). In addition, Chia et al demonstrated that, among men, those in the highest tertile of leptin concentrations had a 3.3-fold (95\% confidence interval: 1.2-8.7) increased colorectal adenoma risk compared with those in the lowest tertile (5). However, Nakajima et al and Kumor et al reported that colon cancer patients had lower or similar serum levels of leptin compared with cancer-free controls $(7,8)$.

Leptin is mainly synthesized and secreted by adipocytes and its plasma levels in humans are strongly correlated with BMI. In the study of Chia et al (5), the majority of the cancer patients were overweight, whereas Kumor et al (7) and Nakajima et al (8) investigated colon cancer patients with normal body weight. Thus, overweight colon patients may have a different leptin status, and the serum leptin levels may differ among various races. The results of our study suggested
Table II. Associations between preoperative serum leptin levels and clinicopathological factors in colon cancer.

\begin{tabular}{|c|c|c|c|}
\hline Factors & $\begin{array}{c}\text { No. of } \\
\text { cases }(\%)\end{array}$ & $\begin{array}{l}\text { Serum leptin } \\
\text { level (ng/ml) }\end{array}$ & P-values \\
\hline \multicolumn{4}{|l|}{ Gender } \\
\hline Male & $29(46.0)$ & $22.18 \pm 11.34$ & \multirow[t]{2}{*}{$>0.05^{\mathrm{a}}$} \\
\hline Female & $34(54.0)$ & $23.09 \pm 13.61$ & \\
\hline \multicolumn{4}{|l|}{ Age (years) } \\
\hline$<60$ & 25 (39.7) & $22.06 \pm 12.02$ & \multirow[t]{2}{*}{$>0.05^{\mathrm{a}}$} \\
\hline$\geq 60$ & $38(60.3)$ & $23.07 \pm 13.10$ & \\
\hline \multicolumn{4}{|l|}{ T stage } \\
\hline $\mathrm{T} 1 / \mathrm{T} 2$ & $26(41.3)$ & $23.01 \pm 14.25$ & \multirow{2}{*}{$>0.05^{\mathrm{b}}$} \\
\hline $\mathrm{T} 3 / \mathrm{T} 4$ & 37 (58.7) & $23.67 \pm 11.37$ & \\
\hline \multicolumn{4}{|l|}{ TNM stage } \\
\hline $\mathrm{I} / \mathrm{II}$ & $16(25.4)$ & $16.89 \pm 9.53$ & \multirow[t]{2}{*}{$<0.05^{\mathrm{b}}$} \\
\hline III & 47 (74.6) & $24.64 \pm 13.59$ & \\
\hline \multicolumn{4}{|c|}{ Differentiation } \\
\hline High & $13(20.6)$ & $18.98 \pm 11.35$ & \multirow[t]{3}{*}{$<0.05^{\mathrm{b}}$} \\
\hline Moderate & $22(34.9)$ & $21.78 \pm 13.91$ & \\
\hline Poor & $28(44.5)$ & $25.08 \pm 12.06$ & \\
\hline \multicolumn{4}{|l|}{ p-mTOR } \\
\hline Negative & 18 (28.6) & $15.97 \pm 8.97$ & \multirow[t]{2}{*}{$<0.05^{\mathrm{b}}$} \\
\hline Positive & 45 (71.4) & $25.35 \pm 14.00$ & \\
\hline \multicolumn{4}{|c|}{ p-70S6 kinase } \\
\hline Negative & $19(30.2)$ & $17.89 \pm 10.97$ & \multirow[t]{2}{*}{$<0.05^{\mathrm{b}}$} \\
\hline Positive & $44(69.8)$ & $24.74 \pm 13.25$ & \\
\hline \multicolumn{4}{|l|}{ p-Akt } \\
\hline Negative & $16(25.4)$ & $16.93 \pm 9.82$ & \multirow[t]{2}{*}{$<0.05^{\mathrm{b}}$} \\
\hline Positive & 47 (74.6) & $24.62 \pm 13.49$ & \\
\hline \multicolumn{4}{|l|}{ Leptin } \\
\hline Negative & $15(23.8)$ & $15.78 \pm 8.21$ & \multirow[t]{2}{*}{$<0.05^{\mathrm{b}}$} \\
\hline Positive & $48(76.2)$ & $24.82 \pm 13.91$ & \\
\hline
\end{tabular}

${ }^{a}$ MannWhitney U test. ${ }^{b}$ Bivariate Pearson correlation. TNM, tumor-node-metastasis; mTOR, mammalian target of rapamycin.

that, in overweight Chinese patients with colon carcinoma, the serum levels of leptin were significantly higher when compared with those of cancer-free controls, and the level decreased significantly following colectomy.

Akt $/ \mathrm{mTOR} / 70 \mathrm{~S} 6 \mathrm{~K}$ is a critical pathway for tumor growth and progression. p-Akt activates mTOR, which subsequently phosphorylates 70S6K, inducing translation of mRNA and finally cell growth (12). In the present study, the serum level of leptin was significantly associated with focal expression of leptin, p-Akt, p-mTOR and P-70S6K. In addition, significant differences in serum leptin levels between various histopathological grades of colon carcinoma were observed. Previous studies also demonstrated that leptin may regulate proliferation and apoptosis of colorectal carcinoma through the phosphoinositide 3-kinase/Akt/mTOR signalling pathway (12). These results suggested that leptin may promote progression of colon cancer through the Akt/mTOR/70S6K signaling 
pathway. However, further studies are required to establish an association between the leptin and Akt/mTOR/70S6K pathways in colon carcinogenesis.

In conclusion, the serum level of leptin was found to be higher in overweight Chinese colon cancer patients, and decreases following colectomy. In addition, the serum leptin level was found to be significantly associated with focal expression of leptin and, factors promoting carcinogenesis, such as p-Akt, p-mTOR and P-70S6K. Thus, leptin may be associated with colon carcinogenesis, and the serum leptin level may be used for early diagnosis and monitoring of the response to treatment of colon carcinoma in overweight Chinese patients.

\section{Acknowledgements}

This study was supported by grants from the Health Department of Hunan Province (B2014-144), the Changsha Municipal Science and Technology Bureau (k1406015-61) and the Key Research and Development Program of Hunan Province (2016SK2066).

\section{References}

1. Considine RV, Sinha MK, Heiman ML, Kriauciunas A, Stephens TW, Nyce MR, Ohannesian JP, Marco CC, McKee LJ, Bauer TL, et al: Serum immunoreactive-leptin concentrations in normal-weight and obese humans. N Engl J Med 334: 292-295, 1996.

2. Maffei M, Halaas J, Ravussin E, Pratley R, Lee G, Zhang Y, Fei H, Kim S, Lallone R, Ranganathan S, et al: Leptin levels in human and rodent: Measurement of plasma leptin and ob RNA in obese and weight-reduced subjects. Nat Med 1: 1155-1161, 1995.
3. Baratta M: Leptin-from a signal of adiposity to a hormonal mediator in peripheral tissues. Med Sci Moni 8: RA282-RA292, 2002.

4. Garofalo C and Surmacz E: Leptin and cancer. J Cell Physiol 207: 12-22, 2006.

5. Chia VM, Newcomb PA, Lampe JW, White E, Mandelson MT, McTiernan A and Potter JD: Leptin concentrations, leptin receptor polymorphisms and colorectal adenoma risk. Cancer Epidemiol Biomarkers Prev 16: 2697-2703, 2007.

6. Stattin P, Lukanova A, Biessy C, Söderberg S, Palmqvist R, Kaaks R, Olsson T and Jellum E: Obesity and colon cancer: Does leptin provide a link? Int J Cancer 109: 149-152, 2004.

7. Kumor A, Daniel P, Pietruczuk M and Malecka-Panas E: Serum leptin, adiponectin, and resistin concentration in colorectal adenoma and carcinoma (CC) patients. Int J Colorectal Dis 24: 275-281, 2009.

8. Nakajima TE, Yamada Y, Hamano T, Furuta K, Matsuda T, Fujita S, Kato K, Hamaguchi T and Shimada Y: Adipocytokines as new promising markers of colorectal tumors: Adiponectin for colorectal adenoma and resistin and visfatin for colorectal cancer. Cancer Sci 101: 1286-1291, 2010.

9. Sung JJ, Lau JY, Goh KL and Leung WK; Asia Pacific Working Group on Colorectal Cancer: Increasing incidence of colorectal cancer in Asia: Implications for screening. Lancet Oncol 6: 871-876, 2005.

10. Calle EE and Kaaks R: Overweight, obesity and cancer: Epidemiological evidence and proposed mechanisms. Nat Rev Cancer 4: 579-591, 2004.

11. Wang D, Chen J, Guo F, Chen H, Duan Z, Wei MY, Xu QM, Wang LH and Zhong MZ: Clinical significance of mTOR and p-mTOR protein expression in human colorectal carcinomas. Asian Pac J Cancer Prev 12: 2581-2584, 2011.

12. Wang D, Chen J, Chen H, Duan Z, Xu Q, Wei M, Wang L and Zhong M: Leptin regulates proliferation and apoptosis of colorectal carcinoma through PI3K/Akt/mTOR signalling pathway. J Biosci 37: 91-101, 2012. 